\title{
PHƯƠNG PHÁP THĂM DÒ HUYẾT ĐỘNG BẦNG CATHETER ĐộNG MẠCH PHỔI Ở BỆNH NHÂN PHẪU THUẬT TIM
}

\author{
Bùi Đức Phú, Huỳnh Văn Minh, Đoàn Đức Hoằng, Hoàng Anh Tiến, Nguyễn Tất Dũng
}

\section{I. ĐĂT VẤN ĐỀ}

Thăm dò huyết động là lĩnh vực quan trọng đã được nghiên cứu áp dụng để theo dõi hồi sức bệnh nhân trong và sau phẫu thuật. Đây là kỹ thuật nghiên cứu các yếu tố đảm bảo vận chuyển và phân bố khối lượng máu đến các cơ quan trong cơ thể. Đầu những năm 70 , hai chuyên gia tim mạch H. J. C. Swan và W. Ganz phát minh một loại catheter gọi là catheter Swan-Ganz luồn được vào trong động mạch phổi nên còn được gọi là catheter động mạch phồi [65]. Catheter này được thiết kế thêm một bóng ở đầu xa có thể bơm lên được để dễ dàng luồn từ tĩnh mạch chủ rồi xuống nhĩ phải, thất phải, và cuối cùng vào trong động mạch phổi. Đây được xem là một cuộc cách mạng trong việc thăm dò huyết động xâm nhập. Sự xuất hiện loại catheter này là bước tiến bộ quan trọng trong lĩnh vực nghiên cứu sinh lý học tim mạch, đặc biệt cần thiết trong việc chẩn đoán cũng như hướng dẫn hồi sức huyết động giai đoạn trong và sau phẫu thuật tim.

Kỹ thuật thăm dò huyết động bằng catheter động mạch phổi có thể tiến hành ngay tại phòng hồi sức, khổng cần thiết phải tiến hành ở phòng thông tim và không đòi hỏi nhiều trang thiết bị tốn kém. Úng dụng của kỹ thuật này để thăm dò huyết động đã được áp dụng tại nhiều trung tâm hồi sức ở các nước trên thế giới để đo các áp lực buồng tim, áp lực động mạch phổi, đo lường các yếu tố quyết định hiệu suất tim như cung lượng tim, bão hoà oxy của máu tĩnh mạch trộn... Đây là một kỹ thuật xâm nhập nên có những hạn chế nhất định so với các phương pháp thăm dò huyêt động không xâm nhập như siêu âm tim qua thực quản, hoặc gần đây nhất là kỹ thuật đo lưu lượng tim theo nguyên lý điện thể sinh học qua các miếng dán điện cực ở vùng cố - ngực. Tuy nhiên, việc sử dụng catheter động mạch phổi để chẩn đoán và theo dõi huyết động trên lâm sàng vẫn rất thông dụng nhất là trong lĩnh vực gây mê hồi sức sau phẫu thuật tim vì đánh giá toàn diện, chính xác huyết động và phát hiện được những bất thường huyết động. Năm 1998, Sandham cho rằng kỹ thuật catheter đồng mạch phổi vẫn là kỹ thuật đưa ra được những thông số đánh giá huyết động một cách đáng tin cậy nhất giúp các nhà hồi sức tiên lượng và hồi sức bệnh nhân một cách hiệu quả nhất.

Ở Việt nam, kỹ thuật catheter động mạch phổi (Pulmonary Artery Catheterization: PAC) được áp dụng còn ít nhưng chưa được nghiên cứu sâu ngay cả ở các trung tâm hồi sức lớn như Hà nội, Huê hoặc Thành phố Hồ Chí Minh. Do vậy, chúng tôi thực hiện chuyên đề: "Phương pháp thăm dò huyết động bằng catheter động mạch phổi ở bệnh nhân phẫu thuật tim" nhằm tìm hiểu:

1. Kỹ thuật thăm dò huyết động xâm nhập bằng catheter động mạch phổi;

2. Đặc điểm các thông số huyết động đo bởi catheter động mạch phổi;

3. Ứng dụng kỹ thuật thăm dò huyết động bằng catheter động mạch phổi trong điều trị hồi sức bệnh nhân phẫu thuật tim.

\section{THĂM DÒ HUYẾT ĐỘNG BẰNG CATHETER ĐỘNG MẠCH PHỔI}

\subsection{Nguyên lý catheter động mạch phổi}

- Loại catheter động mạch phổi kinh điển cấu tạo gồm nhiểu lỗ, dài khoảng $110 \mathrm{~cm}$, và có một đầu nối với một bộ phận chuyển đổi áp lực (transducer).

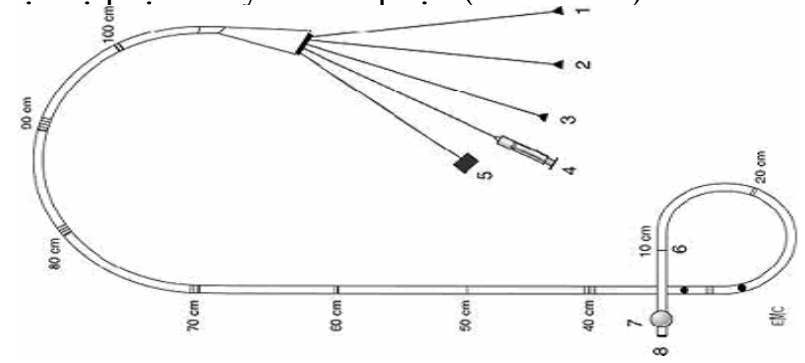

Hình 1. Cấu tạo catheter động mạch phổi

- Đầu mút catheter là lỗ xa để đo áp lực động mạch phổi (PAP). Bóng catheter có thể tích 1,5ml ở ngay phía sau đầu mút và một điện trở nhiệt nằm cách vị trí của bóng khoảng $4 \mathrm{~cm}$ với mục đích đo sự biến thiên nhiệt độ để đo cung lượng tim $(\mathrm{CO})$.

- Mỗi catheter có câu tạo thêm hai lỗ ở vị trí cách đầu mút catheter $19 \mathrm{~cm}$ và $30 \mathrm{~cm}$ tương ứng với khoảng cách từ đầu mút catheter (trong nhánh động mạch phổi) đến thất phải và nhĩ phải với mục đích đo áp lực nhĩ phải (RAP) hoặc áp lực tĩnh mạch trung tâm (CVP) và áp lực thất phải (RVP).

- Một số loại catheter có thiết kê bao phủ bề ngoài tẩm heparin nhằm giảm tạo huyết khối và có thêm đường dẫn truyền với mục đích dẫn nhịp thất tạm thời khi cần thiết.

- Ngoài ra, có một cáp gắn catheter động mạch phổi với màn hình theo dõi để chuyển các tín hiệu dạng sóng và tín hiệu áp lực lên màn hình.

\footnotetext{
* Trung tâm Tim mạch, Bệnh viện Trung Uơng Hué. Ngườ chịu trách nhiệm khoa học: GS.TS. Bùi Đức Phú Ngày nhận bài: 20/07/2015 - Ngày Cho Phép Đăng: 20/08/2015 Phản Biện Khoa họ: PGS.TS. Đặng Ngocc Hùng
} PGS.TS. Lê Ngọc Thành 
- Dẫn truyền tín hiệu áp lực từ cơ thể lên màn hình theo dõi qua dây truyền dịch cấu tạo bán cứng, không đàn hồi và dây dẫn truyền này được đuổi sạch bọt khí với dung dịch nước muối đẳng trương pha heparin. Hệ thống dây dẫn truyền có gắn bộ phận chuyển đổi tín hiệu rồi kết nối với monitor bởi một cáp dẫn truyền tín hiệu.

\subsection{Chỉ định và chống chỉ định}

\subsubsection{Chi định đặt catheter động mạch phổi}

Mặc dù catheter động mạch phổi đã được sử dụng phổ biến hơn bốn thập niên qua, nhưng đển nay vẫn chưa có khuyến cáo cụ thể về chỉ định sử dụng catheter động mạch phổi. Một số bài báo trình bày những đề xuất của các tác giả về chỉ định và chống chỉ định sử dụng catheter động mạch phổi. Có nhiều hội nghề nghiệp và khuyến cáo chuyên khoa đã đưa ra những đồng thuận về vấn đề này. Trường môn Tim mạch Hoa Kỳ (American College of Cardiology) ra xuất bản năm 1998 về đồng thuận sử dụng catheter động mạch phổi ở các bệnh nhân có bệnh lý tim mạch và cho ràng kỹ thuật catheter động mạch phồi đặc biệt cần thiết trong chẩn đoán tăng áp phổi. Khuyến cáo chung sử dụng catheter động mạch phổi (PAC) trong thực hành lâm sàng như sau:

a) Chi định catheter động mạch phổi $P A C$ với muc đích chẩn đoán

- Chẩn đoán tình trạng sốc

- Chẩn đoán phân biệt phù phổi do áp lực phổi cao hay thấp

- Chẩn đoán tăng áp phổi nguyên phát

- Chẩn đoán bệnh van tim, luồng thông trong tim, chèn ép tim, và thuyên tắc phổi.

- Theo dõi đánh giá và điều trị nhồi máu cơ tim cấp biến chứng

- Đánh giá đáp ứng huyết động với điều trị

- Đánh giá tình trạng suy đa tạng và/hoặc tình trạng bỏng nặng

- Đánh giá tình trạng không ổn định huyết động sau phẫu thuật tim

- Đánh giá đánp ứng với điều trị ở bệnh nhân tăng áp phổi nguyên phát

b) Chi định catheter động mạch phổi PAC với muc đích điều trị

- Điều trị hút các thuyên tắc mạch phổi do bọt khí

2.2.2. Chống chi định đặt catheter động mach phổi

Đồng thuận của ACC 1998 không khuyến cáo cho bệnh lý tim mạch như sau:

- Bệnh nhân mang van ba lá cơ học hoặc van động mạch phổi cơ học

- Bệnh lý khối tim phổi (huyết khối và/hoặc u)

- Viêm nội tâm mạc vùng van ba lá hoặc vùng van động mạch phổi

\section{III. ĐĂC ĐIỂM DẠNG SÓNG ÁP LỰC VÀ CÁC THỒNG SỐ HUYẾT ĐỘNG} sinh lý

\subsection{1. Áp lực nhĩ phải}

Các dạng sóng áp lực trong các buồng tim bên phải và bên trái đều có những đặc điểm sinh lý tương đồng, nhưng vẫn có những đặc điểm khác nhau.

- Áp lực tĩnh mạch trung tâm (CVP) và áp lực nhĩ phải (RAP) có giá trị bằng với áp lực tâm trương thất phải (RVDP) trong trường hợp không có bệnh lý tim phổi.

- Áp lực trung bình của tĩnh mạch trung tâm và nhĩ phải dao động từ $0-5 \mathrm{mmHg}$, và biến thiên theo những biến đổi của áp lực trong lồng ngực cùng với nhịp hô hấp.

- Tâm nhĩ phải co bóp làm thay đổi áp lực bên trong, vì vậy áp lực nhĩ phải phụ thuộc vào thể tích tuần hoàn. Tâm nhĩ phải co bóp tạo sóng áp lực gọi là sóng $\mathrm{A}$. Sóng $\mathrm{C}$ lồi nhỏ được nhìn thây khi đắt đầu đoạn xuống của sóng $\mathrm{A}$ và tạo bởi do đóng thứ phát van ba lá. Đoạn xuống bắt đầu sau sóng $\mathrm{A}$ gọi là đoạn xuống $\mathrm{X}$. Đoạn dốc này của đường biểu diễn áp lực nhĩ phải RAP tạo bởi do nhĩ phải dãn và do chuyển động hạ thấp của van ba lá. Tiêp theo đó là sóng $\mathrm{V}$, có hình dạng nhỏ hơn sóng $\mathrm{A}$ một chút, sóng $\mathrm{V}$ phản ánh sự đổ đầy nhĩ phải trong giai đoạn tâm thất thu. Đoạn xuống $\mathrm{Y}$ xảy ra sau sóng $\mathrm{V}$ và biểu thị sự đổ đầy nhanh của thất phải sau khi mở van ba lá.

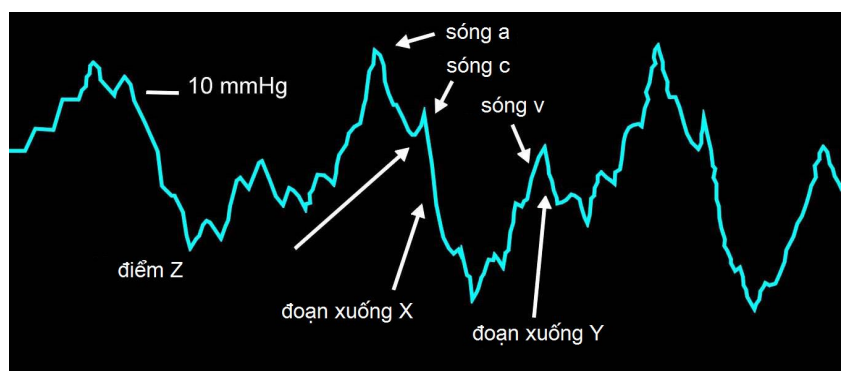

Hình 2. Biến thiên dạng sóng áp lục tĩnh mạch trung tâm (CVP).

- CVP tăng cao hay gặp trong suy cả hai tâm thất. Những nguyên nhân khác gây tăng áp lực nhĩ phải do trào ngược qua van ba lá hoặc hẹp van ba lá, tăng áp phổi, quá tải dịch, viêm màng ngoài tim co thắt, và chèn ép tim.

- Sự hiện diện sóng A rộng, sóng đại bác, xảy ra khi nhĩ phải co bóp mạnh trong khi van ba lá đang đóng. Sóng A đại bác được phát hiện trong một số trường hợp rối loạn nhịp tim, bao gồm nhịp bộ nối và nhịp nhanh thất, và ở những bệnh nhân đang được dẫn nhịp thất pacemakers. Sóng $\mathrm{V}$ lớn xuất hiện trong những trường hợp có trào ngược qua van ba lá, với biên độ tùy thuộc vào kích thước và độ đàn hồi của nhĩ phải.

\subsection{2 Áp lực động mạch phổi}

- Trên đường biếu diến áp lực động mạch phổi (PAP), sóng dạng đường dốc lên do tâm thât phải co bóp 
(thì tâm thu), và một sóng dội ngược dạng nóc tạo bởi trên đường dốc xuống do các van động mạch phổi đóng lại. Áp lực động mạch phổi tâm thu bình thường có giá trị từ 20-30mmHg và bằng với áp lực thất phải tâm thu.

- Áp lực động mạch phổi tăng cao trong những trường hợp tăng lưu lượng máu lên phổi (ví dụ, tăng thể tích tuân hoàn), suy thất trái, và những trường hợp sức cản lớn (bệnh lý tăng áp phồi, bệnh lý van hai lá).

\subsection{3 Áp lực động mạch phổi bít}

- Khi đầu catheter được đặt đúng vị trí và bóng catheter được bơm lên, thì dạng sóng áp lực động mạch phổi sẽ biến mất và thay vào đó là dạng sóng áp lực động mạch phổi bít. Điều này xảy ra do khi bơm bóng làm đầy đầu catheter vào sâu thêm (xấp xỉ $2 \mathrm{~cm}$ ) vào trong nhánh nhỏ của động mạch phổi, và ở vị trí này dòng máu lên phổi sẽ bị chặn lại bởi bóng phồng. Đường biểu diễn áp lực vì vậy không có mạch đập và được gọi là áp lực động mạch phổi bờ PCWP (áp lực động mạch phổi bít PAOP).

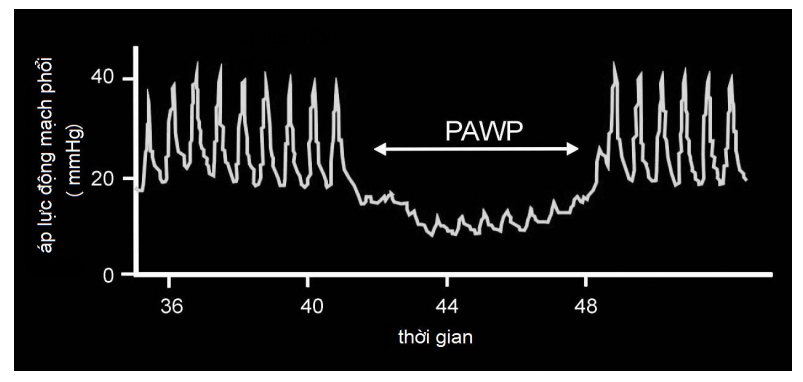

Hình 3. Dạng sóng áp lục động mạch phổi bít (PAWP).

- Áp lực động mạch phổi bít có giá trị bằng áp lực nhĩ trái nếu đầu catheter động mạch phổi ở đúng vị trị vùng có nhu mô phổi bình thường và không có sự tắc nghẽn các mạch máu phổi. Khi bơm phồng bóng catheter sẽ ngăn cản dòng máu đi lên từ thất phải và sẽ tạo một cột máu thông thương giữa lỗ xa ở đầu catheter với nhĩ trái.

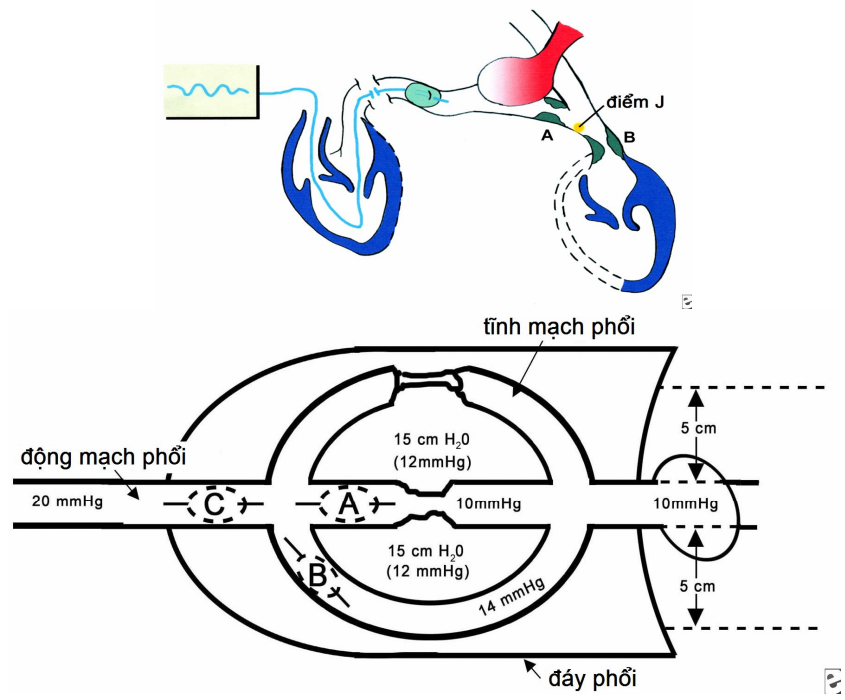

Hình 4. Bóng catheter phồng trong động mạch phổi để đo áp lực ở điểm $J$.
- Dạng sóng áp lực động mạch phổi bít PAWP phản ánh những thay đổi áp lực bên trong nhĩ trái. Các sóng $\mathrm{A}, \mathrm{C}$, và $\mathrm{V}$ tạo thành bởi hoạt động co bóp của nhĩ trái tương tự với của nhĩ phải.

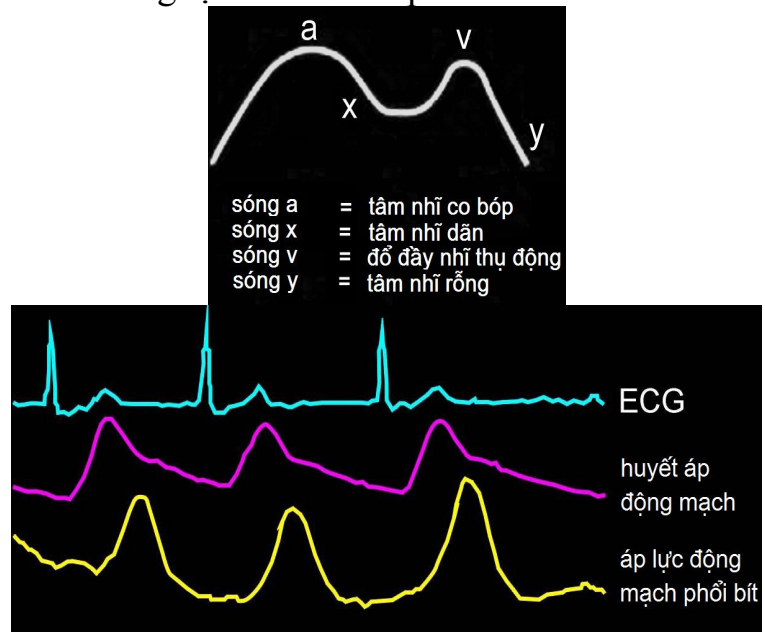

Hình 5. Dạng sóng áp lục nhĩ trái hoặc nhĩ phải.

- Các dạng sóng áp lực có thể được nhận biết bằng cách theo dõi đồng thời $\mathrm{ECG}$ và các đường biểu diễn áp lực trên cùng một monitor. Thời gian của sóng áp lực động mạch phổi liên quan với sóng điện tâm đồ trên monitor, trong đó sóng áp lực $\mathrm{A}$ tương ứng với sóng $\mathrm{QRS}$ trên $\mathrm{ECG}$, còn sóng áp lực $\mathrm{V}$ tương ứng với sóng T trên ECG.

* Phân chia các vùng phổi theo West

- Ở zone 1 (vùng đỉnh phổi), áp lực phế nang (PALV) cao hơn cả áp lực động mạch phổi trung bình PAMP và áp lực tĩnh mạch phổi (PVP), nên lưu lượng máu phụ thuộc vào áp lực phế nang PALV. Ở zone 2 (vùng phổi trung tâm), áp lực động mạch phổi PAP cao hơn áp lực phế nang PALV, và áp lực này cao hơn áp lực tĩnh mạch phổi PVP, do đó lưu lượng máu phụ thuộc vào cân bằng giữa $\mathrm{PAP}$ và $\mathrm{PALV}$. Do có những mao mạch phổi bị xẹp, nên ở zone 1 và zone 2 không có những thông thương trực tiếp với nhĩ trái. Ở zone 3 (vùng đáy phổi), áp lực phế nang là PALV thấp hơn áp lực động mạch phổi PAP và áp lực tĩnh mạch phổi, nên thường không có vùng xẹp mao mạch và dòng máu không bị gián đoạn mà thông thương trực tiếp với nhĩ trái. Điều này giải thích giá trị của áp lực động mạch phổi bít chỉ phản ánh đúng áp lực nhĩ trái khi đầu catheter động mạch phổi được đặt đúng vào vị trí mạch máu ở zone 3.

- Khi đặt bệnh nhân tư thế nằm ngửa, việc luồn đầu catheter động mạch phổi thường thuận lợi vào đúng vị trí mạch máu ở zone 3 giúp đo chính xác giá trị áp lực nhĩ trái vì lưu lượng máu ở zone 3 thường tăng, dễ dàng đẩy trôi bóng đang được bơm phồng. Ơ những bệnh nhân hồi sức đòi hỏi chể độ thở máy với áp lực dương cuối thì thở ra (PEEP) với mức độ 
$\mathrm{PEEP}>10 \mathrm{cmH}_{2} \mathrm{O}$, thì vùng zone 3 có thể bị giảm lưu lượng máu. Chụp $\mathrm{x}$-quang lồng ngực thẳng kiểm tra vị trí của đầu catheter động mạch phổi ngang mức nhĩ trái là đúng vị trí mong muốn, tuy nhiên có thể chụp thêm phim lồng ngực tư thế nghiêng nếu cần thiết. Nếu vẫn chưa xác định được vị trí của đầu catheter, cần kiểm tra khí máu được hút ra từ lỗ xa ở đầu catheter sau khi đã bơm phồng bóng.

\subsubsection{Cung luọng tim}

- Cung lượng tim $\mathrm{CO}$ có thể được đo bởi catheter động mạch phồi PAC bằng các phương pháp khác nhau. Cung lượng tim có thể được tính theo nguyên lý Fick, đó là định luật về sự bảo toàn và trạng thái cân bằng giữa cung và cầu của một chất sự khác biệt về nồng độ của chất đó giữa máu động mạch và máu tĩnh mạch. Trong trường hợp sử dụng catheter động mạch phổi để đo cung lượng tim, thì chất đó là oxygen, và cung lượng tim $\mathrm{CO}$ được tính theo công thức sau: $\mathrm{CO}=\mathrm{VO}_{2} /\left(\mathrm{CaO}_{2}-\mathrm{CvO}_{2}\right)$

Nhiều loại catheter động mạch phối cho phép đo cung lượng tim $\mathrm{CO}$ bằng phương pháp pha loãng chất chỉ thị gọi đó là phương pháp pha loãng nhiệt độ. Phương pháp này hiệu quả hơn vì bơm chất chỉ thị không bị dội lại và không phải lấy máu xét nghiệm. Bơm nhanh một thể tích $(5-10 \mathrm{~mL})$ biêt trước dung dịch nước muối sinh lý lạnh (thường $\leq 25^{\circ} \mathrm{C}$ ) vào lỗ gần của catheter vào tâm nhĩ phải. Điện trở nhiệt phía đầu catheter động mạch phổi sẽ giúp theo dõi sự biến thiên nhiệt độ của máu, và trên monitor sẽ biểu hiện một đồ thị biểu diễn sự biến thiên nhiệt độ theo thời gian.

Biến thiên nhiệt độ do máu tĩnh mạch ấm pha loãng với dung dịch bơm vào tỉ lệ nghịch với cung lượng tim. Phương trình Stewart-Hamilton để tính cung lượng tim theo phương pháp pha loãng nhiệt như sau: $\mathrm{Q}=\mathrm{V}_{1}\left(\mathrm{~Tb}-\mathrm{T}_{1}\right) \mathrm{k}_{1} \mathrm{k}_{2} / \mathrm{Tb}(\mathrm{t}) \mathrm{dt}$.

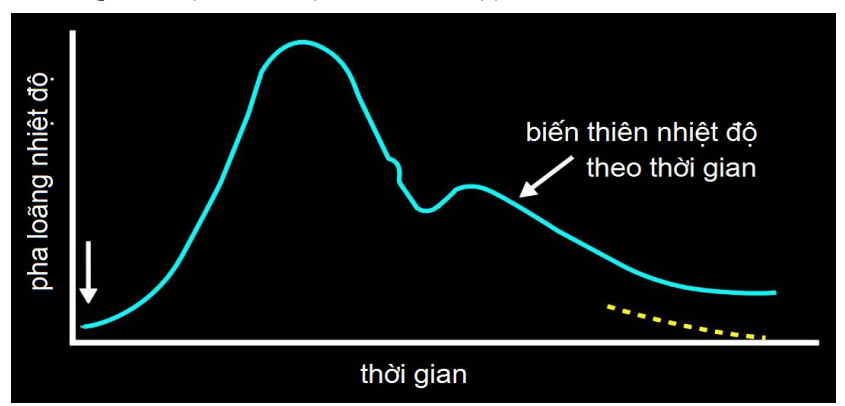

Hình 7. Nguyên lý đo cung lương tim.

- Phương trình Stewart-Hamilton giải thích những sai sót trong quá trình thực hiện kỹ thuật dẫn đến những sai số giảm xuống hoặc tăng lên khi đo cung lượng tim. Bơm dung dịch ra ngoài hoặc động tác bơm cẩu thả với chỉ một thể tích dung dich nhỏ hơn cần thiết làm sai số và đồ thị biểu diễn biến thiên nhiệt độ theo thời gian với biên độ thấp, điều này làm cho giá trị cung lượng tim $\mathrm{CO}$ tăng cao giả tạo. Nguyên nhân có thể do hệ thống bị hở, có luồng thông phải-trái trong tim, do động tác bơm dung dịch không đủ nhanh, và do catheter không được luồn vào đúng vị trí. Ngược lại, bơm quá nhiều dung dịch hoặc động tác bơm quá chậm làm cho giá trị cung lượng tim đo được bị giảm thấp giả tạo. Sai sót về nhiệt độ có thể gặp nểu truyền dịch liên tục. Huyết khối hoặc đầu catherter áp thành mạch máu có thể làm hỏng chức năng điện trở nhiệt dần đến sai số.

\subsubsection{Bão hòa oxy máu tĩnh mạch trộn $\mathrm{S} \bar{v} \mathrm{O}_{2}$}

Bão hòa oxy máu tĩnh mạch trộn $\mathrm{S} \mathrm{O}_{2}$ là giá trị biểu thị kết quả cuối cùng sự cung cấp oxy và tiêu thụ oxy ở mô cơ quan: $\mathrm{S}_{\overline{\mathrm{V}}} \mathrm{O}_{2}=\mathrm{O}_{2}$ cung cấp $-\mathrm{O}_{2}$ bị tiêu thụ.

Khi có nguy cơ mât cân bằng giữa cung - cầu oxy thì cơ thể sẽ bù trừ; kết quả của sự bù trừ này được phản ánh qua giá trị $\mathrm{S}_{\bar{V}} \mathrm{O}_{2}$. $\mathrm{S} \overline{\mathrm{O}}_{2}$ bình thường chứng tỏ cung cấp oxy đầy đủ cho mô ; Giá trị $\mathrm{S} \bar{v} \mathrm{O}_{2}$ thấp có ý nghĩa hoặc là cung cấp oxy không đầy đủ, hoặc do nhu cầu oxy gia tăng. Cho dù nguyên nhân nào thì khi $\mathrm{Sv}_{2}$ giảm chứng tỏ cơ thể không còn khả năng duy trì cân bằng oxy và cần phải can thiệp điều trị thích đáng.

Đo lường bão hòa oxy của máu trong động mạch phổi, máu trở về từ tĩnh mạch chủ trên, tĩnh mạch chủ dưới và từ xoang vành. $\mathrm{Kỹ}$ thuật đo $\mathrm{SV}_{\mathrm{v}} \mathrm{O}_{2}$ dựa trên phương pháp chụp phổ tia phản chiếu. Phổ ánh sáng của các sóng được dần truyền theo sợi quang học được tích hợp bên trong catheter. Phổ quang này sau đó được truyền về một bộ phận cảm nhận sóng quang ở module quang học của màn hình theo dõi. Vì hemoglobin và oxyhemoglobin hấp thụ ánh sáng khác nhau từ các sóng phồ quang nên bộ phận cảm nhận sóng quang có thể phân tích được tỉ lệ phần trăm độ bão hòa oxy $\mathrm{SV}_{2}$.

Trong giới hạn bình thường $\mathrm{S} \mathrm{O}_{2}$ (60\%-80\%), người thầy thuốc có thể đánh giá sự tưới máu mô là đầy đủ. Giá trị $\mathrm{S} \overline{\mathrm{V}} \mathrm{O}_{2}<60 \%$ do giảm phân tách oxy hoặc do tăng tiêu thụ oxy. Giá trị $\mathrm{S}_{\bar{v}} \mathrm{O}_{2}<40 \%$ khi khả năng bù của cơ thể bị hạn chế, và oxy không đủ để cung cấp cho mô. Bảng sau minh họa trường hợp lâm sàng gây nên mất cân bằng cung - cầu oxy. Giá trị $S \bar{v} \mathrm{O}_{2}$ cao có thể do kỹ thuật luồn catheter đang được bơm bóng vào sâu nên máu từ lỗ xa catheter là máu gần các phế nang giàu oxy nên có độ bão hòa oxy cao như trong máu động mạch. Đôi khi, giá trị $\mathrm{S} \overline{\mathrm{V}} \mathrm{O}_{2}$ bình thường hoặc gia tăng ở một số bệnh nhân vốn đã có đủ tiêu chuẩn chẩn đoán thiếu oxy mô. Có 3 nguyên nhân sau:

- Hiện tượng trộn lẫn máu tĩnh mạch và máu động mạch do có luồng thông giữa động - tĩnh mạch : trường hợp này lượng oxy phân tách cho mô $\left(\mathrm{QT}_{\text {(total) }}\right.$ $\mathrm{x} \mathrm{CaO}_{2}$ ) chia 2 phần : một phần phân tách $\mathrm{O}_{2}$ thật sự khi luồng máu qua mô $\left(\mathrm{Qc} \times \mathrm{CaO}_{2}\right)$; phần còn lại theo luồng thông (shunt) nối tắt giữa động mạch tĩnh mạch mà không đi qua mô $\left(\mathrm{Qs} \times \mathrm{CaO}_{2}\right)$. Hiện tượng mở shunt này thường gặp trong bệnh lý sốc nhiễm trùng.

- Những bất thường phân bố lưu lượng máu góp phần làm gia tăng giá trị $\mathrm{S} \overline{\mathrm{V}} \mathrm{O}_{2}$ trong trường hợp vận chuyển oxy không đủ. Bình thường, cơ thể bù trừ bằng cách giảm lưu lượng máu đến các mô có nhu cầu oxy thấp để cung cấp một lưu lượng bổ sung cho các mô có nhu 
cầu oxy cao hơn. Nếu sự tái phân bố tưới máu này không xảy ra thì sẽ có hiện tượng thiếu oxy ở các mô không nhận đủ oxy trong khi ở các mô có nhu cầu oxy thấp thì lại được tưới máu quá mức. Máu trở về sau khi qua các mô có nhu cầu oxy thấp sẽ có nồng độ oxy cao gây tăng $\mathrm{S}^{\mathrm{v}} \mathrm{O}_{2}$ cho dù các mô khác bị thiếu oxy.

- Thiếu oxy mô do ngộ độc tế bào: ở các bệnh nhân giảm tiêu thụ oxy có thể do các men oxy hóa bị bất hoạt hoặc giảm một phần chức năng. Điều này dẫn đến nồng độ oxy trong máu sau khi qua mô vẫn cao xấp xỉ trong máu động mạch và $S \bar{v} \mathrm{O}_{2}$ gia tăng. Tại mô, sự ứ đọng nồng độ cao oxy gây ngộ độc tế bào và điều này được thấy ở bệnh nhân ngộ độc cyanide do sử dụng liệu pháp điều trị với nitroprusside.

Bảng 1. Úng dụng lâm sàng của $\mathrm{S} \bar{v} \mathrm{O}_{2}$

\begin{tabular}{|c|c|c|c|}
\hline Giá trị & & nghĩa & Xử trí lâm sàng \\
\hline \multirow{6}{*}{$\begin{array}{c}\mathrm{S} \bar{v} \mathrm{O}_{2} \\
\text { tăng }\end{array}$} & \multirow{2}{*}{\multicolumn{2}{|c|}{$\begin{array}{c}\text { Tăng phân tách oxy } \\
\text { cho mô }\end{array}$}} & Tăng $\mathrm{FiO}_{2}$ \\
\hline & & & Tăng oxy hóa \\
\hline & \multirow{4}{*}{\multicolumn{2}{|c|}{ Giảm nhu cầu oxy }} & Hạ thân nhiệt \\
\hline & & & Gây mê sâu \\
\hline & & & Liệt do thuốc \\
\hline & & & Nhiễm trùng \\
\hline \multirow{5}{*}{$\begin{array}{l}\mathrm{SV}_{2} \mathrm{O}_{2} \\
\text { giảm }\end{array}$} & \multirow{3}{*}{$\begin{array}{c}\text { Giảm } \\
\text { phân } \\
\text { tách } \\
\text { oxy mô }\end{array}$} & Giảm Hb & Thiếu máu, chảy máu \\
\hline & & Giảm $\mathrm{SaO}_{2}$ & Thiếu oxy tổ chức \\
\hline & & $\begin{array}{l}\text { Giảm cung } \\
\text { lượng tim }\end{array}$ & $\begin{array}{l}\text { Giảm thể tích, sốc, } \\
\text { loạn nhịp }\end{array}$ \\
\hline & \multirow{2}{*}{\multicolumn{2}{|c|}{ Tăng nhu cầu oxy }} & Tăng thân nhiệt, đau \\
\hline & & & Run lạnh, cơn tai biến \\
\hline
\end{tabular}

\subsubsection{Tiền gánh (áp lục thất trái cuối tâm thu)}

Áp lực động mạch phổi bít PAWP phản ánh giá trị của áp lực nhĩ trái LAP, và nếu không có bệnh lý van hai lá thì đây là giá trị chỉ điểm của áp lực tâm trương thất trái. Điều này có nghĩa giá trị của áp lực động mạch phổi bít phản ánh thể tích cuối tâm trương của thất trái (LVEDV) hoặc áp lực cuối tâm trương của thất trái (LVEDP).

Áp lực động mạch phổi bít PAWP là phương tiện để đo lường áp lực thủy tĩnh ở mao mạch phồi ( $\mathrm{PCHP})$ và giá trị này giúp đánh giá lượng nước trong phổi. Quan niệm này đúng với giả định kháng lực của hệ tĩnh mạch phổi bằng 0 . Thực tế, hệ thổng mao mạch và tĩ்h mạch phổi chiếm xấp xỉ $40 \%$ của tổng sức cản mạch máu phổi. Giá trị này là cao hơn ở những bệnh nhân hồi sức vốn bị co mạch máu phổi thứ phát do thiếu oxy máu và do hội chứng nguy cập hô hấp cấp (ARDS). Áp lực thủy tĩnh ở mao mạch phổi PCHP luôn luôn lớn hơn áp lực động mạch phổi bít PAWP. PAWP có thể được sử dụng để ước tính giá trị của áp lực thủy tĩnh tại mao mạch phổi PCHP trong phù phổi nếu nguyên nhân là tăng mạn tính áp lực tĩnh mạch phổi PVP, tăng tính thấm, tăng áp lực trong khoang màng phổi, và tăng áp lực thẩm thấu.

\subsubsection{Anh hương của hô hấp đến các dạng sóng} áp lục

Áp lực động mạch phổi bít PAWP còn chịu tác động bởi nhịp hô hấp. Cần phải chọn đúng thời điểm để đo áp lực động mạch phổi bít PAWP bởi vì các áp lực trong lồng ngực có thể biến đổi rất lớn theo nhịp hô hấp hít vào hay thở ra và các áp lực này sẽ tác động lên hệ mạch máu phổi. Trong thì hít vào tự nhiên, áp lực trong lồng ngực giảm xuống (áp lực âm); trong thì thở ra, áp lực trong lồng ngực tăng lên (áp lực dương). Thông khí chủ động (ví dụ, ở bệnh nhân được đặt ống nội khí quản) làm đảo ngược tình trạng nói trên. Để giảm thiểu tác động của nhịp hô hấp lên các áp lực trong lồng ngực, cần tiến hành đo áp lực động mạch phổi bít PAWP vào thời điểm cuối thì thở ra, khi mà các áp lực trong lồng ngực gần bằng 0 .

Ở những bệnh nhân ADRS nặng thường rất khó để xác định thời điểm cuối thì thở ra. Trong những trường hợp này, cần sử dụng thuốc an thần, hoặc thêm thuốc dãn cơ để loại ảnh hưởng của nhịp hô hấp gắng sức tác động lên đường biểu diển áp lực.

\subsubsection{Tác động của áp lục duơng cuối thì thở ra PEEP}

Áp lực dương cuối thì thở ra PEEP (nội sinh hoặc ngoại sinh) tác động đến hệ mạch máu phổi. Độ đàn hồi của phổi là yếu tố quyết định chính đến tác động áp lực này. Một số tình trạng bệnh lý (ARDS) thường có độ đàn hồi của phổi kém (phổi đông đặc), tác động dẫn truyền áp lực là tối thiểu. Cần phải biết làm cách nào để điều chỉnh áp lực động mạch phổi bít PAWP trong trường hợp sử dụng PEEP. Mặc dù nhiều tác giả trước đây ủng hộ, nhưng việc sử dụng PEEP tạm thời và ngắt quảng có thể có tác dụng đảo ngược, như trụy tim mạch hoặc thiếu oxy máu, mà đây vốn là những hiện tượng khó hồi phục. Khi sử dụng PEEP lớn hơn $10 \mathrm{cmH}_{2} \mathrm{O}$, giá trị của áp lực động mạch phổi bít PAWP cần được điều chỉnh được tính theo công thức như sau.

$\mathrm{PAWP}_{\text {ước muốn }}=\mathrm{PAWP}_{\text {đo được }}-1 / 2(\mathrm{PEEP} / 1,36)$.

Nếu có thể, đặt một bóng để đo áp lực trong thực quản, khi đó

$\mathrm{PAWP}_{\text {ước muốn }}=\mathrm{PAWP}_{\text {đo được }}-\mathrm{P}_{\text {thực quản }}$

3.2. Đặc điểm các dạng sóng áp lực trong điều kiện bệnh lý

Sốc được định nghĩa là sự tưới máu không đủ đáp ứng với các nhu cầu chuyển hóa của mô cơ quan. Dạng thường gặp nhất là sốc giảm thể tích, sốc do tim, sốc nhiễm khuẩn, và sốc do tắc nghẽn. Catheter động mạch phổi thường được sử dụng giúp điều chỉnh sự rối loạn các thông số huyết động được trình bày trong bảng sau. 
Bảng 2. Đặc điểm huyết động trong tình trạng sốc.

\begin{tabular}{|l|c|c|c|c|c|c|}
\hline \multicolumn{1}{|c|}{ Hội chứng sốc } & CVP & PAWP & $\mathrm{CO}$ & $\mathrm{SVR}$ & $\mathrm{VO}_{2}$ & $\mathrm{DO}_{2}$ \\
\hline Sốc do lưu thông máu kém & $0,<$ & $0,<$ & $>$ & $<$ & $<, 0,>$ & $>$ \\
\hline Sốc do tim & $>$ & $>$ & $<$ & $>$ & $<$ & $<$ \\
\hline Sốc giảm thể tích & $<$ & $<$ & $<$ & $>$ & $>$ & $<$ \\
\hline
\end{tabular}

\subsubsection{Sốc giảm thể tích tuần hoàn}

Sốc giảm thể tích do giảm thể tích máu tuần hoàn vì mất máu hoặc mất dịch từ cơ thể. Tiền gánh bị giảm rõ nét, dẫn đến áp lực đổ đầy không đủ. Bệnh nhân bị sốc giảm thể tích có biểu hiện tụt huyết áp và nhịp tim nhanh. Các áp lực trong các buồng tim, trong tĩnh mạch và hệ thống mạch máu bị giảm thấp bất thường. Đường biểu diễn các áp lực của catheter động mạch phổi dao động giảm thấp biên độ.

\subsubsection{Sốc do tim}

Sốc do tim do suy sụp nghiêm trọng hiệu suất tim. Sốc do tim đặc trưng với huyêt áp tâm thu giảm dưới $80 \mathrm{mmHg}$, chỉ số tim giảm dưới 1.8 lít $/ \mathrm{min} / \mathrm{m}^{2}$, và áp lực động mạch phổi bít tăng trên $18 \mathrm{mmHg}$. Dạng sốc này có thể do nguyên nhân trực tiếp từ cơ tim (nhồi máu cơ tim rộng, bệnh lý cơ tim nặng) hoặc nguyên nhân cơ học gây quá tải chức năng cơ tim (trào ngược qua van 2 lá nặng cấp tính, vỡ vách liên thất cấp).

Những nguyên nhân thường gặp của trào ngược qua van hai lá cấp ở phòng ICU là do đứt các trụ cơ dưới van xảy ra thứ phát sau nhồi máu cơ tim cấp, hoặc do thiếu máu cơ tim gây rối loạn chức năng các trụ cơ này, viêm nội tâm mạc nhiễm khuẩn, đứt dây chằng, và do chấn thương. Nguyên nhân khác do bệnh lý thấp hoặc thoái hóa van 2 lá. Trào ngược qua van 2 lá cấp là hiện tượng một lượng máu lớn phụt ngược lên tâm nhĩ trái vốn có độ đàn hồi kém, làm tăng áp lực tĩnh mạch phổi và gây phù phổi. Lúc này thường thấy sóng $\mathrm{V}$ ở trên đường biểu diễn sóng áp lực động mạch phổi bít.

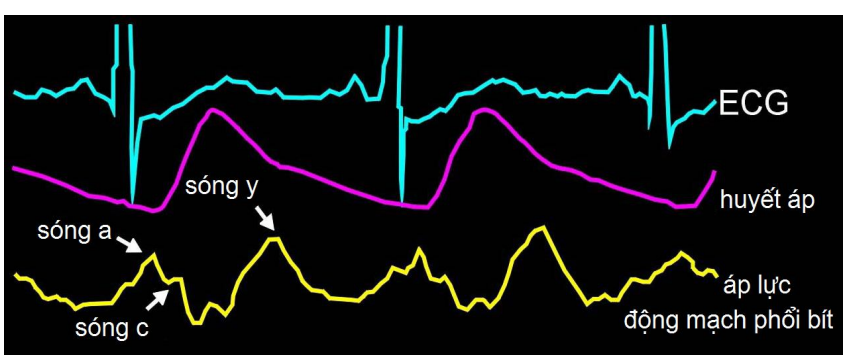

Hình 8. Sóng V rộng trong bệnh lý trào ngược qua van 2 lá.

Dạng sóng động mạch phổi cao khác thường bởi vì sóng $\mathrm{V}$ rộng được biểu thị bởi áp lực dội lại từ nhĩ trái tác động lên hệ mạch máu phổi. Đoạn xuống Y diễn ra rất nhanh vì sự tống máu nhanh chóng từ một tâm nhĩ trái vốn bị dãn quá mức. Cần phân biệt giữa một sóng $\mathrm{V}$ rộng với một sóng áp lực động mạch phổi tâm thu. Nếu nhầm lẫn có thể dẫn đến tiếp tục luồn tiếp catheter động mạch phổi vào sâu hơn để đạt được áp lực động mạch phổi bít sẽ làm tăng nguy cơ thủng động mạch phổi.

Trong bệnh lý trào ngược van 2 lá mạn tính, một thể tích máu đáng kể phụt ngược, và để thích nghi tâm nhĩ trái sẽ bị dãn đáng kể. Ngược lại với bệnh lý trào ngược cấp tính, áp lực nhĩ trái sẽ thấp hơn và thường không có biểu hiện sóng $\mathrm{V}$ dãn rộng.

\subsubsection{Sốc nhiễm khuẩn}

Sốc nhiễm khuẩn là nguyên nhân tử vong thường gặp nhất ở các đơn vị hồi sức tăng cường ICU ở Hoa Kỳ. Sốc nhiễm khuẩn là tình trạng sốc có rối loạn tình trạng lưu thông máu, biểu hiện với dãn mạch ngoại vi. Mặc dù cung lượng tim có thể bình thường hoặc tăng cao nhưng các tạng và mô cơ quan vẫn không được tưới máu đầy đủ. Các loại sốc khác có biểu hiện rối loạn lưu thông máu bao gồm sốc phản vệ, sốc do nguyên nhân thần kinh, và sốc do suy thượng thận. Catheter Swan-Ganz thường giúp phát hiện áp lực đổ đầy giảm thấp trong những trường hợp sốc này.

\subsubsection{Sốc do tắc nghẽ̃n ngoài tim}

Chèn ép tim là một điển hình loại sốc này. Chèn ép tim là do hiện tượng tụ dịch nhanh bất thường trong khoang màng tim. Áp lực khoang màng ngoài tim gia tăng tác động đến sự đổ đầy tâm thất trong thì tâm trương, làm giảm tiền gánh, giảm thể tích nhát bóp, và giảm lưu lượng tim. Điều này có thể xảy ra thứ phát sau nhiễm virus, do u ác tính, do chấn thương, hoặc do tổn thương giập cơ tim. Với sự tích tụ dịch ít khoảng $50 \mathrm{~mL}$ đã có thể tác động đến việc đổ đầy tim trong thì tâm trương, làm giảm cung lượng tim nghiêm trọng. Sự đổ đầy tâm thất bị ảnh hưởng trong suốt thì tâm trương làm ảnh hưởng đến cân bằng vốn có trong thì tâm trương. Khi đó, áp lực nhĩ phải RAP xấp xỉ áp lực tâm trương thất phải, và giá trị này gần bằng với áp lực động mạch phổi tâm trương, và cũng tương đương với giá trị của áp lực động mạch phổi bít.

Dạng sóng áp lực nhĩ phải biểu hiện gồm sóng $\mathrm{X}$ nhỏ lăn tăn, đoạn dốc xuống Y ngắn hoặc biến mất, và áp lực trung bình của nhĩ phải tăng cao. Mất hình ảnh dao động của áp lực động mạch phổi PAP biến thiên theo nhịp thở. Ở những bệnh nhân có chèn ép tim, huyết áp tâm thu hệ thống biểu hiện với sóng mạch đập đảo ngược. Những nguyên nhân khác của sốc do tắc nghẽn ngoài tim bao gồm tràn dịch màng phổi lượng lớn và tràn khí màng phổi gây tăng áp lực. 


\subsubsection{Nhũng bệnh lý tim mạch khác}

\subsubsection{Viêm màng ngoài tim co thắt}

- Sự dày lên của màng ngoài tim là nguồn gốc gây nên bệnh lý viêm màng ngoài tim co thắt. Điều này gặp ở những bệnh nhân có bệnh lý thấp, bệnh lao, ung thư di căn, hoặc do tia xạ vùng lồng ngực hay tiền sử phẫu thuật tim hở trước đây. Nguyên nhân cũng có thể là vô căn. Khoang màng tim dày và kém đàn hồi dẫn đến việc đổ đầy tâm thất bị hạn chế và đến nhanh hơn, biểu hiện dạng sóng cao nguyền trên đường biểu diễn áp lực thất phải trong bệnh lý viêm màng ngoài tim co thắt điển hình. Đây là dạng sóng "chìm dẹt và hình cao nguyên" hay còn gọi là dấu hiệu căn bậc hai; sóng áp lực nhĩ phải có hình dạng đặc trưng hình chũ̃ $\mathrm{M}$ hoặc chữ $\mathrm{W}$. Các sóng $\mathrm{A}$ và sóng $\mathrm{V}$ có các đoạn xuống $\mathrm{X}$ và $\mathrm{Y}$ nhanh và ngắn, tương phản với hình ảnh trong bệnh lý chèn ép tim nêu trên. Giá trị của áp lực động mạch phồi bít có thể tăng cao lên đến $20-25 \mathrm{mmHg}$, và thường có dạng sóng gần giống với dạng sóng áp lực nhĩ phải. Dạng sóng mạch đập đảo ngược ít gặp hơn trong viêm màng ngoài tim co thắt so với trong chèn ép tim.

\subsubsection{Hep van hai lá}

- Trong bệnh lý hẹp 2 lá nặng, áp lực nhĩ trái tăng, nên áp lực động mạch phổi bít tăng cao. Tăng áp phổi tùy theo mức độ nặng tồn thương van. Điều này gây tăng áp lực tâm thu thât phải và gia tăng kích thước sóng $\mathrm{A}$ trên đường biểu diễn áp lực nhĩ phải. Áp lực tâm trương thất phải có thể tăng nếu thất phải suy hoặc do trào ngược qua van 3 lá. Rung nhĩ là biến chứng thường gặp trong hẹp hai lá và làm mất biểu hiện sóng $\mathrm{A}$ trên cả đường biểu diễn áp lực nhĩ phải và đường biểu diễn áp lực động mạch phối bít.

\subsubsection{Hep van đông mach chủ}

- Hẹp van động mạch chủ có thể là hẹp trên van, hẹp tại van, hoặc hẹp dưới van. Các dạng sóng nhĩ phải RAP, thất phải $\mathrm{RVP}$, và động mạch phổi $\mathrm{PAP}$ thường có hình dạng bình thường trừ khi hẹp van diễn tiến đến suy tim sung huyết. Dang sóng áp lực động mạch phổi bít PAWP có thể biểu hiện với sóng $\mathrm{A}$ dãn rộng trong những trường hợp hẹp nặng do độ đàn hồi của thất trái giảm.

\subsubsection{Hở van động mach chủ}

- Những bất thường về huyết động khác nhau giữa các bệnh lý hở van động mạch chủ cấp tính và mạn tính. Hở van động mạch chủ cấp tính thường gặp nhất do viêm nội tâm mạc nhiễm khuẩn, chấn thương ngực, bóc tách động mạch chủ lên, và do thoái hóa các lá van. Biểu hiện rối loạn huyết động trong bệnh lý hở van động mạch chủ cấp tính bao gồm tăng nhẹ các giá trị áp lực tâm thu và tâm trương trong nhĩ phải và thất phải. Các áp lực tâm thu và tâm trương trong động mạch phổi và áp lực động mạch phổi bít cũng tăng. Quan sát đường biểu diễn huyết áp động mạch hệ thống đôi khi có thể thấy dạng sóng dãn rộng và cao không có sóng nóc dội lại. Hở van động mạch chủ cấp và mạn tính thường có những biểu hiện tương phản nhau; dạng sóng áp lực mạch đập dãn rộng thường không được thấy trong hở van động mạch chủ cấp tính.

Bảng 3. Ý nghĩa lâm sàng và ích lợi của các thông số huyết động đo bởi catheter động mạch phổi PAC ở các bệnh lý tim mạch

\begin{tabular}{|c|c|c|}
\hline Bệnh lý tim mạch & Thông số huyết động PAC & Ý nghĩa lâm sàng / cách sử dụng \\
\hline \multirow{5}{*}{$\begin{array}{l}\text { Tổn thương chức } \\
\text { năng thất trái tâm } \\
\text { thu }\end{array}$} & 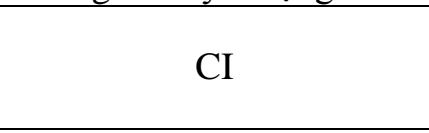 & $\begin{array}{l}\text { Đạt mục đích lâm sàng }\left(\mathrm{CI}>2,41 / \mathrm{phút} / \mathrm{m}^{2}\right) \\
\text { Đánh giá hiệu quả liệu pháp inotrope } \\
\text { Đánh giá đáp ứng liệu pháp bù dịch }\end{array}$ \\
\hline & PAWP & $\begin{array}{l}\text { Áp lực đổ đầy thất trái } \\
\text { Đánh giá đáp ứng liệu pháp bù dịch } \\
\text { Đánh giá hiệu quả của liệu pháp inotrope/sử dụng thuốc giãn mạch }\end{array}$ \\
\hline & PAP & $\begin{array}{l}\text { Phát hiện tăng áp phồi trước mao mạch hay tăng áp phồi sau } \\
\text { mao mạch } \\
\text { Theo dõi liên tục tiền gánh thất trái }\end{array}$ \\
\hline & SVR & Phát hiện co mạch ngoại biên \\
\hline & $\mathrm{S} \overline{\mathrm{V}} \mathrm{O}_{2}$ & $\begin{array}{l}\text { Đánh giá hiệu quả liệu pháp điều trị dãn mạch } \\
\text { Đạt mục đích lâm săng }\left(\mathrm{SvO}_{2}>75 \%\right) \\
\text { Phát hiện mất cân bằng cung-cầu } \mathrm{O}_{2}\left(\mathrm{DO}_{2}, \mathrm{VO}_{2}\right) \\
\text { Đánh giá cung lượng tim CI đáp ứng nhu cầu cơ thể hay không } \\
\text { Đánh giá hiệu quả thuốc và liệu pháp bù dịch }\end{array}$ \\
\hline \multirow{7}{*}{$\begin{array}{l}\text { Tổn thương chức } \\
\text { năng thất phải }\end{array}$} & CI & Như trên \\
\hline & $\mathrm{S} \overline{\mathrm{V}} \mathrm{O}_{2}$ & Như trên \\
\hline & PAWP & Như trên \\
\hline & CVP & tiền gánh thất phải, thế tích lòng mạch \\
\hline & PVR & $\begin{array}{l}\text { Phát hiện tăng áp phối } \\
\text { Hướng dẫn liệu pháp NO, cài máy thở }\end{array}$ \\
\hline & RVEF & Đánh giá co bóp thât phải \\
\hline & RVEDV & Đánh giá tiền gánh thất phải \\
\hline chức & $\mathrm{CI}$ & Như trên \\
\hline
\end{tabular}




\begin{tabular}{|c|c|c|}
\hline \multirow{2}{*}{$\begin{array}{l}\text { năng thất trái tâm } \\
\text { trương }\end{array}$} & $\mathrm{S \textrm {V }} \mathrm{O}_{2}$ & Như trên \\
\hline & PAWP & $\begin{array}{l}\text { Như trên, đặc biệt cần thiêt đánh giá đáp ứng với liệu pháp } \\
\text { bù dịch. Phát hiện những thay đồi giai đoạn chuyển tiếp từ } \\
\text { rối loạn chức năng tâm trương thất trái độ II sang độ III }\end{array}$ \\
\hline \multirow{2}{*}{$\begin{array}{l}\text { Thủng vách liên } \\
\text { thất cấp }\end{array}$} & $\mathrm{CI}$ & $\begin{array}{l}\text { CI tăng bất thường gợi ý luồng thông tái phát sau đóng thông } \\
\text { liên thất }\end{array}$ \\
\hline & $\mathrm{S} \overline{\mathrm{V}} \mathrm{O}_{2}$ & $\begin{array}{l}\mathrm{S} \overline{\mathrm{V}} \mathrm{O}_{2} \text { tăng bất thường giúp chẩn đoán luồng thông tái phát } \\
\text { sau đóng VSD }\end{array}$ \\
\hline \multirow{5}{*}{ LVAD } & CVP & Đánh giá tiền gánh thất phải và thể tích tuần hoàn người bệnh \\
\hline & PVR & Phát hiện tăng áp phôi tiền mao mạch \\
\hline & & Sử dụng NO, đánh giá hiệu quả liệu pháp NO \\
\hline & RVEF & Đánh giá sức co bóp và tiền gánh thât phải \\
\hline & $\mathrm{S} \overline{\mathrm{V}} \mathrm{O}_{2}$ & $\begin{array}{l}\text { Đánh giá lưu lượng của thiết bị LVAD có đáp ứng nhu cầu } \\
\text { chuyền hóa không }\end{array}$ \\
\hline
\end{tabular}

\section{KẾT LUẬN}

Phương pháp thăm dò huyết động bằng catheter động mạch phổi đã được nghiên cứu và phát triển tại nhiều trung tâm hồi sức trên thế giới. Đây được xem là tiêu chuẩn vàng trong đánh giá huyết động ở bệnh nhân hồi sức đặc biệt là bệnh nhân sau mổ tim vốn đòi hỏi theo dõi liên tục các dữ liệu về chức năng tim mạch sau phẫu thuật sửa chữa các thương tổn ở tim. Kỹ thuật tiến hành không quá phức tạp nhưng đây là một kỹ thuật xâm nhập cần được cân nhắc kỹ hiệu quả sử dụng. Các thông số huyết động đo bởi catheter động mạch phổi rất hữu ích trong hồi sức huyết động bao gồm áp lực tĩnh mạch trung tâm CVP, áp lực nhĩ phải RAP, áp lực thất phải RAP, phân suất tống máu thất phải RVEF, áp lực động mạch phổi PAP, áp lực động mạch phổi bít PAWP và các thông số đánh giá hiệu suất của cả hệ thống tim - phổi như cung lượng tim $\mathrm{CO}$ và bão hòa oxy máu tĩnh mạch trộn $\mathrm{S}_{\bar{V}} \mathrm{O}_{2}$.

Nghiên cứu huyết động bằng catheter động mạch phổi nhằm tìm hiểu các giá trị áp lực trong các buồng tim và trong các mạch máu lớn. Hơn nữa, việc tìm hiểu và phân tích dạng sóng áp lực và đặc điểm của các thông số huyết động đo bởi catheter động mạch phổi giúp phát hiện các dấu hiệu góp phần chẩn đoán tình trạng bệnh lý tim mạch và điều này đặc biệt hữu ích trong hồi sức huyết động cho những bệnh nhân nặng có nguy cơ cao. Catheter động mạch phổi không phải sử dụng thường qui trong phẫu thuật tim mà chỉ sử dụng để theo dõi huyết động cho những bệnh nhân có nguy cơ đáng kể, đặc biệt ở những bệnh nhân có nguy cơ rối loạn huyết động do bệnh lý tim mạch và do phẫu thuật tim. Dựa vào đánh giá và phân tích các đặc điểm thông số huyết động mà người thầy thuốc có hướng điều trị hồi sức phù hợp và chính catheter động mạch phổi cũng là phương tiện đánh giá hiệu quả của các liệu pháp điều trị này.

\section{TÀI LIỆU THAM KHẢO}

1. Binanay C, Califf RM, Hasselblad V, et al. (2005), Evaluation study of congestive heart failure and pulmonary artery catheterization effectiveness: the ESCAPE trial. JAMA. Oct 5 2005;294(13):1625-33.

2. Bojan Paunovic, MD (2007), Pulmonary Artery Catheterization., Sat Sharma, MD, $\operatorname{FRCP}(C)$, FCCP, FACP, DABSM, Contributor Information and Disclosures. Updated: Dec 20, 2007.

3. Chatterjee K. (2009), The Swan-Ganz catheters: past, present, and future. A viewpoint. Circulation. Jan 6 2009;119(1):147-52.

4. Edwards Lifesciences (2007), "Incorporating Continous Cardiac Output and $\mathrm{SvO}_{2}$ at the Bedside", Understanding continous mixed venous oxygen saturation $\left(\mathrm{SvO}_{2}\right)$ monitoring with the Swan-Ganz oximetry TD system, $2^{\text {nd }}$ Edition, pp. 17-20.

5. Greenberg SB, Murphy GS, Vender JS. (2009), Current use of the pulmonary artery catheter. Curr Opin Crit Care. Jun 2009;15(3):249-53.

6. Harvey S, Harrison DA, Singer M, et al. (2005), Assessment of the clinical effectiveness of pulmonary artery catheters in management of patients in intensive care (PAC-Man): a randomised controlled trial. Lancet. Aug 6-12 2005;366(9484):472-7.

7. Jacka MJ, Cohen MM, To T, Devitt JH, Byrick R (2002), The appropriateness of the pulmonary artery catheter in cardiovascular surgery. Can J Anesth 2002, 49:276-282.

8. Jacka MJ, Cohen MM, To T, Devitt JH, Byrick R (2002), The use and preferences for the transesophageal echocardiogram and pulmonary artery catheter among cardiovascular anesthesiologists. Anesth Analg 2002, 94:1065-1071.

9. Jondeau Guillaume, Jean-Pierre Bourdarias (1998), "Étude quantitative de la fonction cardiaque", Traité de Cardiologie, 11-002-A-40. 58. 